\title{
GC-C-IRMS analysis of FAMEs as a tool to ascertain the diet of lberian pigs used for the production of pork products with high added value
}

\author{
By C. Recio $^{a, *}$, Q. Martín ${ }^{\mathrm{b}}$ and C. Raposo ${ }^{\mathrm{c}}$ \\ a Stable Isotope Laboratory and Geology Dept., ${ }^{b}$ Dept. of Statistics, ${ }^{c}$ Mass Spectrometry Laboratory. \\ Facultad de Ciencias, Universidad de Salamanca; Plaza de los Caidos, s/n; E37008 Salamanca, Spain \\ *Corresponding author: crecio@usal.es
}

\section{RESUMEN}

Análisis de ácidos grasos mediante GC-C-IRMS como herramienta para discernir la dieta del Cerdo Ibérico empleado en la producción de artículos de alto valor añadido

El sabor, la calidad y los efectos saludables de los derivados del cerdo ibérico dan lugar a una elevada demanda de los mismos, tanto en fresco como curados. Las características mencionadas responden a una dieta y crianza específicas (libres en la Dehesa, alimentándose de lo que ésta produce). Frecuentemente, los recursos disponibles son insuficientes para cubrir la demanda, dando en ocasiones lugar a la alimentación artificial de algunos de los cerdos. El análisis de las relaciones isotópicas ${ }^{13} \mathrm{C} /{ }^{12} \mathrm{C}$ de los ácidos grasos Palmítico, Esteárico, Oleico y Linoleico mediante GC-C-IRMS permite diferenciar entre animales criados al estilo tradicional (acabados en montanera) y aquellos alimentados con piensos. El valor de $\delta^{13} \mathrm{C}_{\mathrm{C} 18: 1}=-25.9 \%$ os un buen indicador, pero la correcta asignación de una muestra dada requiere el empleo de los cuatro ácidos grasos indicados y su tratamiento estadístico mediante análisis de componentes principales.

PALABRAS CLAVE: Control de calidad $-\delta^{13} \mathrm{C}-$ Isótopos estables - Jamón curado.

\section{SUMMARY}

GC-C-IRMS analysis of FAMEs as a tool to ascertain the diet of Iberian pigs used for the production of pork products with high added value

Taste, quality and perceived health benefits result in a high demand for both green and mature pork products derived from the lberian bred swine. These characteristics are directly related to diet and breeding style (free ranging in a particular Mediterranean ecosystem: the Dehesa). Given that current demand is not matched by the available resources, animal feed is increasingly used. GC-C-IRMS analysis of Palmitic, Stearic, Oleic and Linoleic Acid methyl esters allows for differentiating between pork raised in the traditional way and that fattened on animal feed. Although a value of $\delta^{13} \mathrm{C}_{\mathrm{C} 18: 1}$ $=-25.9 \%$ is a good discriminator, exploratory analysis of principal canonical components is required to properly assign any unknown sample.
KEY-WORDS: Cured ham $-\delta^{13} C-$ Quality assurance Stable isotopes.

\section{INTRODUCTION}

Traditionally, the Iberian pig breed has been reared in an extensive fashion in the "Dehesa", a distinctive ecosystem of the western and southern Iberian Peninsula, feeding on natural resources all year long, with a major contribution by acorns in the winter months, just prior to slaughter; a method known as "Montanera". For centuries, perhaps even a millennium, such practices followed the natural balance, with both "good" years and less-so ones so that the quantity and quality of the product mirrored the resources available.

The increased consumer demand for the high quality pork products derived from the "Iberian" swine breed has resulted in an ever-increasing production, decoupled from natural cycles or from a matching increase in available natural resources. In actual fact, the natural habitat of the Iberian pig has suffered a notable reduction, resulting in a concomitant modification of the traditional breeding and fattening practices. The high animal density required to meet market demands cannot be sustained by the Dehesa on its own, leading to a substantial number of animals being reared in an unnatural fashion; mostly on formulated feed.

The high quality of Iberian pork products, and subsequent consumer appreciation and willingness to pay a high price for them, derives from the traditional breeding and feeding system, making it mandatory to devise a method to differentiate among the final commercial products, such as matured hams or cured loins, with regards to different rearing styles and foods.

The Administration has reacted to this need by creating PDO's (protected designation of origin;

\footnotetext{
1 The "Dehesa" is a managed Mediterranean forest, populated by Quercus evergreens, that was cleared for pastures, extending for some $2 \times 10^{5} \mathrm{Km}^{2}$ in the Iberian Peninsula.

${ }^{2}$ The Spanish term "Montanera" refers both to acorn foraging in the "Dehesa" ecosystem, mostly by pigs, and to the time the pigs spend feeding that way.
} 
for example, "Guijuelo"3) and dictating norms (RD 1083/2001) which establish quality standards. This resulted in a three-category classification: "Cebo" (animals raised on animal feed), "Recebo" (for animals raised on natural foods, but finished on formulated feed) and "Bellota" (for animals bred according to tradition, on a free-range basis and exclusively fed on grass and winter acorns). Pork is classed into one or another category as per Order PRE/3844/2004, where the official sampling and analytical methods are described, and establishes gas chromatography of fatty acids as the technique of choice.

As a reaction, swine producers sought for pig feeds that match the analytical parameters expected by Orden PRE/3844/2004, and it is possible to find formulated feeds with added fats, whose fatty acid profile approaches that expected from a completely natural feeding regime. Realization of this situation led to dropping any and all analytical controls in an updated quality norm (RD 1649/2007), which were replaced by in situ inspections by auditors accredited according to UNE EN ISO/IEC 17020 norm.

The need exists, therefore, for finding alternative objective methods that cannot be easily fouled, and stable isotopes may be one such technique. $C$ isotope ratios essentially reflect the diet of an organism (although enriched by about 1\%。; DeNiro and Epstein, 1978), and its application to the characterization of whole Iberian swine products has been reported before (González-Martín, et al., 2001; González-Martín, et al.,1999). The use of formulated feeds with added fats, selected to result in a given fatty acid profile, however, can show up in (at least some of) the results, rendering them at best non-conclusive. Compound-Specific Isotopic Characterization techniques (CSIC), however, are more difficult to falsify, since multiple parameters are determined simultaneously on a single sample. GC-C-IRMS methods (Gas Chromatography Combustion - Isotope Ratio Mass Spectrometry) allow for the determination of ${ }^{13} \mathrm{C} /{ }^{12} \mathrm{C}$ ratios in several FAMEs, leading to a "fingerprint" that is characteristic of each individual sample (see MeierAugenstein, 2002, for a review). In this regard, the techniques applied make use of formerly official methods, in the sense that they analyze the chromatographic profile of the swine fat, but go a step beyond by determining its $C$ isotopic signature as well.

\section{SAMPLES AND METHODS}

The "Guijuelo" PDO Council supplied us with a set of 159 samples of fat collected according to official methods (Orden PRE/3844/2004). Of these, 28 samples (labelled "98 B.Pienso") were from "white" pigs (non-lberian breed; authorized varieties of lberian breed swine are all black or dark brown), raised in enclosures on formulated feed. 18 samples (labelled "10 lb. Pienso") were from Iberian swine raised on a free-range basis, but fed animal feed. Three batches, respectively comprising 25 ("31 lb. Recebo"), 18 (“32 lb. Recebo") and 14 ("33 lb. Recebo") samples were declared as "Recebo", while the remaining three groups (of $10-" 65 \mathrm{lb}$. Bellota"-, 23 -"66 lb. Bellota"- and 23 -"67 lb. Bellota"- samples) had been classed as "Bellota". Since the research reported was conceived as a blind test of the ability of stable isotopes to differentiate among the different classes, the authors accepted the samples "bona fide" as supplied, and were not involved in their selection, collection or classification.

Additionally, two types of animal feed ("Pienso N", a formulated pig feed with added fats, and "Pienso L", made exclusively with mixed cereals), and some acorns -10 from holm-oaks ${ }^{4}$ ("Bellota Encina") and 2 from the less frequent cork oak ${ }^{5}$ ("Bellota Alc")- were collected during the 200607 winter season. Given that soy beans, corn, sunflower seeds, ... are common components of animal feed, in addition to cereals, we got several different commercial edible oils (olive, sunflower, corn, wheat germ, linseed, $2 / 3$ sunflower $+1 / 3$ soy bean, and sesame seed oil) and analyzed them for reference.

Orden PRE/3844/2004 describes gas chromatography of fatty acid methyl esters (FAMEs) as the official method to differentiate among classes, together with the sampling and sub-sampling protocols to be used, and the accepted fat extraction and methylation techniques. As such, about $5 \mathrm{~g}$ of the fat samples were melted by the microwave method (de Pedro, Casillas \& Miranda, 1996); filtered while still hot through 20$25 \mu \mathrm{m}$ filter paper (Whatman \# 41 or equivalent; Whatman International Ltd, Maidstone, Kent, UK), allowed to cool and stored frozen at $-20^{\circ} \mathrm{C}$ until further processing.

Fat from pig feeds and acorns was obtained following Spanish Official Methods of Analysis (RD 609/1999) by soxhlet extraction, employing a SER148 automated soxhlet extractor (VELP Scientifica srl, 20040 Usmate, Ml, Italy) operated at $150{ }^{\circ} \mathrm{C}$ for $30 \mathrm{~min}$, and petroleum ether as solvent (PANREAC Química SAU, E08211 - Castellar del Vallés, Barcelona, Spain; lot no.0000102674). After extraction, the excess solvent was eliminated in a Laborota 4000 efficient rotary evaporator (Heidolph Instruments $\mathrm{GmbH}$ \& Co. KG, 91126 Schwabach, Germany) operated at $45^{\circ} \mathrm{C}$. As for the adipose

\footnotetext{
${ }^{3}$ http://www.magrama.gob.es/es/alimentacion/temas/calidad-agroalimentaria/calidad-diferenciada/dop/jamon/DOP JamonGuijuelo.aspx

${ }^{4}$ Quercus ilex. Subspecies Q. i. ilex and Q. i. ballota are dominant in the area being considered.

${ }^{5}$ Quercus suber.
} 
tissue, the extracted fat was filtered while still warm, and stored frozen until required. Since it is common knowledge in the countryside that Iberian swine does not eat the skin of the acorns, but rather has the ability to peel them off, acorns were processed both whole and without the skin, in order to test for differences.

Methylation of the fatty acids was done on 85 $\mathrm{mg}$ of the extracted fat, which were dissolved in 4 $\mathrm{ml} \mathrm{n-hexane} \mathrm{("Chromasolv"} \mathrm{quality;} \mathrm{Sigma-Aldrich}$ Chemie GmbH, 89555 Steinheim, Germany; lot no. $8267 \mathrm{~A}$ ). To this, $200 \mu \mathrm{L}$ of a $2 \mathrm{M} \mathrm{KOH}$ in methanol solution were added (Sigma-Aldrich Chemie $\mathrm{GmbH}, 89555$ Steinheim, Germany; $\mathrm{KOH}$ : 99.99\%, semiconductor grade; methanol anhydrous, 99.8\%, lot no. 02953DE-346), and following vigorous shaking, it was left to rest for $30 \mathrm{~min}$. After centrifugation (30 secs at $2000 \mathrm{rpm}$ ), about $2 \mathrm{ml}$ of the FAME solution were collected in suitable septum capped GC vials, discarding the remaining solution. If samples were not to be analyzed immediately, they were kept frozen at $-20{ }^{\circ} \mathrm{C}$.

Mass spectrometry analyses were done on a quadrupolar Shimadzu QP5000 GCMS system with a GC-17 gas chromatograph (Shimadzu Europa GmbH, 47269 Duisburg, Germany). Injections were done with an AOC-20i automatic injector. The column used was a J\&W scientific DB-WAX capillary column with a length of $30 \mathrm{~m}$ and an ID of $0.25 \mathrm{~mm}$ (Agilent Technologies, Inc., Life Sciences and Chemical Analysis Group, Santa Clara, CA 95051-7201, USA). The film thickness was $0.25 \mu \mathrm{m}$. Helium with a purity higher than 99.999\% was used as carrier gas (Praxair España S.L., 28020 Madrid, Spain); an Excelasorb inline purifier (Chromatographic Specialties Inc., Brockville, Ontario K6V 5W1, Canada) was used to reduce the residual amounts of oxygen, water and hydrocarbons. Column flow was $1.1 \mathrm{~mL} \mathrm{~min}^{-1}$. Injector and interface temperatures were $230{ }^{\circ} \mathrm{C}$. The temperature program was as follows: initial conditions $130^{\circ} \mathrm{C}$, kept for $3 \mathrm{~min}$, then a ramp at $15^{\circ} \mathrm{C} \min ^{-1}$ up to $190{ }^{\circ} \mathrm{C}$. At that point the ramp was changed to $2{ }^{\circ} \mathrm{C} \min ^{-1}$ up to $230^{\circ} \mathrm{C}$. This temperature was kept for $13 \mathrm{~min}$. Mass spectra were recorded from 50 to $500 \mathrm{amu}$. The samples $(1.0 \mu \mathrm{L})$ were injected in split mode (split ratio 1:5). Individual FAMEs were identified according to their mass spectrum as reported in the NIST98 mass spectra database and the elution time as expected for their Kovats retention index.

Isotopic analyses were done on a GC-C-IRMS

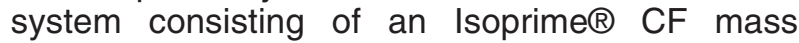
spectrometer coupled to an Agilent GC System 6890 Series Plus + via a combustion interface, designed and manufactured by Micromass (presently, Isoprime Ltd., Cheadle, SK8 6PT, UK). Chromatography used an SGE "Forte BPX70" capillary column, $30 \mathrm{~m}$ long, $0.32 \mathrm{~mm}$ ID and 0,25 $\mu \mathrm{m}$ phase thickness (SGE Analytical Science Pty Ltd, Victoria 3134, Australia), and $\mathrm{He}$ as carrier gas. Injector and detector temperatures were both $280{ }^{\circ} \mathrm{C}$. Samples were injected in split mode (25:1), as were the reference materials, although for these the split ratio was $4: 1$. Samples were injected via an automatic injector in batches consisting of 18 unknowns bracketed by two references. The injection volume was $0,1 \mu \mathrm{L}$ for both samples and references. These chromatographic conditions correctly separate FAMEs from C13:0 to C21:0. Reproducibility of our internal $\mathrm{C} 17: 0$ reference (methyl-heneicosanoate; see below; accepted $\delta^{13} C_{\text {VPDB }}=-30.56 \%$ o varied from $\pm 0.30 \%$ o $(1 \sigma$; $\mathrm{n}=10)$ to $\pm 0.12 \%$ 。 $(1 \sigma ; n=6)$. Overall reproducibility during the time required to complete the analyses was $\pm 0.26 \%$ o $(1 \sigma ; n=60)$. Methodological improvements were done after the analyses were reported and have lowered these figures to \pm $0.11 \%$ o $(1 \sigma ; n=95)$.

A problem common to every GC-C-IRMS analysis is the lack of internationally accepted, officially certified reference materials. To overcome this we have prepared our own references for routine use. To that end, we acquired three commercial FAMEs (methyl-tridecanoate, methylheneicosanoate, and methyl-heptadecanoate; respective lot and filling codes 1190621 \& $43306172 ; 1301314$ \& 53106078; 1223678 \& 31806142), originally intended as GC reference materials, from Sigma-Aldrich. Each FAME was repeatedly analyzed for its $C$ isotopic composition as received by means of EA-IRMS (Elemental Analyzer, Isotope Ratio Mass Spectrometry), together with official reference materials NBS22 (crude oil; $\delta^{13} \mathrm{C}_{\mathrm{VPDB}}=-30.03 \%$ ), USGS-24 (graphite; $\delta^{13} \mathrm{C}_{\mathrm{VPDB}}=-16.45 \%$ ) and IAEA-CH-6 (sucrose; $\delta^{13} C_{V P D B}=-10.45 \%$ ), in order to calibrate them individually. Once sufficiently determined by this method, they were dissolved in $n$-hexane and mixed together to a final concentration of the same order of magnitude as that of our unknown FAMEs. As an additional control we have frequently used references "Mixture A" and "Mixture B" from Indiana University 6 .

Isotopic results are reported in the common "Delta" notation as \%o $\left(\right.$ per mill) ${ }^{7}$ relative to VPDB:

$$
\delta(\% \circ)=\frac{R_{\text {Sam }}-R_{\text {Ref }}}{R_{\text {Ref }}} \times 1.000
$$

$\mathrm{R}_{\text {Sam }}$ and $\mathrm{R}_{\text {Ref }}$ are the ${ }^{13} \mathrm{C} /{ }^{12} \mathrm{C}$ isotopic ratios of sample and reference gas.

\footnotetext{
${ }^{6}$ Prepared by Dr. A. Schimmelmann; Dept. of Geol. Sciences, Biogeochem. Laboratories; see http://mypage. iu.edu/ aschimme/hc.html

7 ISO 31-0, Quantities and Units, Part 0, General Principles, subclause 2.3.3; International Organization for Standardization: Geneva, 1993.
} 
Actual data returned by the mass spectrometer data system are deviations relative to the mass spectrometer working gas. To transform these values into values relative to VPDB we have used the expression:

$$
\delta_{\mathrm{VPDB}}=\delta_{\mathrm{m}}+\delta_{\mathrm{VPDB}}^{\mathrm{Ref}}+\frac{\delta_{\mathrm{m}} \times \delta_{\mathrm{VPDB}}^{\mathrm{Ref}}}{1.000}
$$

$\delta_{\mathrm{VPDB}}$ : Corrected value relative to VPDB.

$\delta_{\mathrm{m}}$ : measured value relative to the working gas.

$\delta_{\mathrm{VPDB}}^{\mathrm{Ref}}$ : Isotopic value of the working gas relative to VPDB.

In practical terms, data reduction employed the values determined for the reference samples and the worksheets written by Dr. P. Brooks (Center for Stable Isotope Biogeochemistry; Univ. of California at Berkeley ${ }^{8}$ ), modified to suit our needs.

Correction of the measured $\delta^{13} \mathrm{C}_{\mathrm{VPDB}}$ values to take into account the $C$ introduced by methanol during derivatization used the formula of Goodman and Brenna (1992). The methanol we used has $\delta^{13} \mathrm{C}_{\mathrm{VPDB}}=-44.49 \pm 0.07 \%$ o $(1 \sigma ; \mathrm{n}=5)$ (as measured by GC-C-IRMS on the same instrument as the FAMEs).

\section{RESULTS}

Table 1 is a summary of the descriptive statistics for the $\delta^{13} \mathrm{C}_{\text {VPDB }}$ values obtained. The full data set has been represented as binary plots in Fig. 1. A data table with individual analyses is available from the senior author upon request.

The results indicate that four fatty acids are present in every sample at a high concentration. These are, in relative order of abundance, Oleic (C18:1), Palmitic (C16:0), Linoleic (C18:2) and Stearic (C18:0) acid. Other fatty acids, either less abundant or not present in every sample, have also been determined, but are not considered in the discussion. Representative GC-C-IRMS "chromatograms" are available from the senior author upon request.

From Fig. 1.a, b, c it is evident that Oleic Acid (C18:1) is a good discriminator of the animal's feeding regime, with samples classed as Bellota having values of $\delta^{13} \mathrm{C}_{\mathrm{C} 18: 1} \leq-25.9 \%$, which is in good agreement with the fact that the lowest isotopic values measured are those of the acorns, whatever the FAME being considered. Despite a limited number of samples, it would seem that there are geographical and species-related differences (northernmost acorns from Salamanca have more negative $\delta^{13} \mathrm{C}_{\mathrm{VPDB}}$ values than those from further south in the Iberian Peninsula; holmoak (Quercus ilex) acorns are more negative than cork-oak (Quercus suber) ones). No significant differences were observed, however, between whole and skinless acorns. Since these differences are relatively minor in comparison with data from the adipose tissues measured, we will not elaborate on this subject until further data become available.

Marked differences have been observed for pig feed (Fig. 1.a, c, e). "Pienso $N$ " contains added animal fat, and not surprisingly, plots very close to the field defined by acorns. "Pienso L", on the other hand, included only cereals in its formulation, and has less negative $\delta^{13} \mathrm{C}_{\text {VPDB }}$ values.

Whatever the combination of parameters plotted, Iberian swine raised on pig feed (" $10 \mathrm{lb}$. Pienso") is easy to tell from Recebo and Bellota varieties (Fig. 1), as indicated by heavier and more disperse isotopic values. Samples originally classed as Recebo show striking variability among different lots. Samples labelled as "33 lb. Recebo" have systematically higher $\delta^{13} \mathrm{C}_{\mathrm{VPDB}}$, whatever the FAME considered, indicating minimum weight gain during Montanera, together with the fact that the pig feed supplied to these animals must have consisted mainly of $\mathrm{a} \mathrm{C}_{4}$ plant-derived material; perhaps corn. In this regard, the corn oil analyzed for reference plots towards the heavier end of the field defined by "33 lb. Recebo". The compound-specific isotopic method allows not only for distinguishing among different diets, but also serves to gain an approximate idea of the relative proportions of its main components. This variability comes at no surprise: if the values for individual FAMEs are plotted in histogram form (plots not shown), it is relatively frequent to observe a bimodal distribution, pointing to the fact that lots are frequently not homogeneous, but rather animals raised on different feeding regimes are mixed together for slaughter.

\section{DATA HANDLING}

Normalized data were subjected to exploratory analysis using a commercial statistical package (SPSS). Analysis of variance (one factor ANOVA) confirmed that the mean values of each group of samples were statistically different at the $1 \%$ significance levels (Fig. 2; Table 2). Discriminant analysis is a statistical tool to identify those variables that better separate among groups, and identifies how many of the variables are required for the best classification possible. Discriminant analysis is useful for creating predictive models that allow for assigning a given specimen to a group. The procedure requires creating a set of discriminant functions based on lineal combinations of predictor variables. As such, we

\footnotetext{
${ }^{8}$ http://ib.berkeley.edu/groups/biogeochemistry/downloads.php

9 Spanish for "acorn"
} 
Table 1

Mean $\delta^{13} \mathrm{C}_{\mathrm{VPDB}}$ values of FAMEs, summarized by batch and type

\begin{tabular}{|c|c|c|c|c|c|}
\hline Type & & C16:0 & C18:0 & C18:1 & C18:2 \\
\hline \multirow[t]{3}{*}{ Pienso N (pig feed with added animal fat) } & Mean & -30.60 & & -29.40 & -31.51 \\
\hline & $\mathrm{N}$ & 2 & & 2 & 2 \\
\hline & Std. Deviation & 0.86 & & 1.19 & 0.04 \\
\hline \multirow[t]{3}{*}{ Pienso L (pig feed exclusively cereal-based) } & Mean & -26.76 & -26.87 & -25.63 & -28.68 \\
\hline & $\mathrm{N}$ & 2 & 2 & 2 & 1 \\
\hline & Std. Deviation & 1.72 & 3.94 & 0.52 & \\
\hline \multirow[t]{3}{*}{ Bellotas Encina (holm-oak acorns) } & Mean & -30.40 & -29.20 & -29.73 & -30.49 \\
\hline & $\mathrm{N}$ & 10 & 4 & 10 & 10 \\
\hline & Std. Deviation & 0.85 & 1.68 & 1.51 & 1.06 \\
\hline \multirow[t]{3}{*}{ Bellotas Alcornoque (cork-oak acorns) } & Mean & -28.41 & & -27.69 & -29.85 \\
\hline & $\mathrm{N}$ & 2 & & 2 & 2 \\
\hline & Std. Deviation & 0.64 & & 0.76 & 0.25 \\
\hline \multirow[t]{3}{*}{ Blanco Pienso (white pigs raised on feed) } & Mean & -25.05 & -24.00 & -24.56 & -29.24 \\
\hline & $\mathrm{N}$ & 28 & 28 & 28 & 28 \\
\hline & Std. Deviation & 0.72 & 1.17 & 0.84 & 1.12 \\
\hline \multirow{3}{*}{$\begin{array}{l}\text { Ibérico Pienso (Iberian -dark to black- pigs } \\
\text { raised on feed) }\end{array}$} & Mean & -23.25 & -21.47 & -23.60 & -28.85 \\
\hline & $\mathrm{N}$ & 18 & 18 & 18 & 18 \\
\hline & Std. Deviation & 0.59 & 1.50 & 1.01 & 1.84 \\
\hline \multirow{3}{*}{$\begin{array}{l}31 \text { lb Recebo (mostly acorn fed, finished on } \\
\text { feed) }\end{array}$} & Mean & -24.59 & -23.08 & -25.22 & -28.39 \\
\hline & $\mathrm{N}$ & 25 & 25 & 25 & 25 \\
\hline & Std. Deviation & 0.59 & 0.90 & 0.60 & 0.89 \\
\hline \multirow{3}{*}{$\begin{array}{l}32 \mathrm{lb} \text { Recebo (mostly acorn fed, finished on } \\
\text { feed) }\end{array}$} & Mean & -25.30 & -24.95 & -26.25 & -29.51 \\
\hline & $\mathrm{N}$ & 18 & 18 & 18 & 18 \\
\hline & Std. Deviation & 0.57 & 0.67 & 0.27 & 1.41 \\
\hline \multirow{3}{*}{$\begin{array}{l}33 \text { lb Recebo (mostly acorn fed, finished on } \\
\text { feed) }\end{array}$} & Mean & -19.46 & -19.09 & -21.55 & -22.85 \\
\hline & $\mathrm{N}$ & 14 & 14 & 14 & 14 \\
\hline & Std. Deviation & 1.61 & 1.66 & 1.50 & 1.70 \\
\hline \multirow{3}{*}{$\begin{array}{l}65 \mathrm{lb} \text { Bellota (naturally fattened: grass and } \\
\text { winter acorns) }\end{array}$} & Mean & -26.47 & -25.82 & -27.10 & -31.09 \\
\hline & $\mathrm{N}$ & 10 & 10 & 9 & 10 \\
\hline & Std. Deviation & 0.22 & 0.60 & 0.35 & 0.86 \\
\hline \multirow{3}{*}{$\begin{array}{l}66 \text { Ib Bellota (naturally fattened: grass and } \\
\text { winter acorns) }\end{array}$} & Mean & -25.33 & -24.71 & -26.67 & -29.81 \\
\hline & $\mathrm{N}$ & 23 & 23 & 23 & 23 \\
\hline & Std. Deviation & 0.32 & 0.41 & 0.35 & 0.71 \\
\hline \multirow{3}{*}{$\begin{array}{l}67 \mathrm{lb} \text { Bellota (naturally fattened: grass and } \\
\text { winter acorns) }\end{array}$} & Mean & -25.53 & -24.82 & -26.55 & -29.90 \\
\hline & $\mathrm{N}$ & 23 & 23 & 23 & 23 \\
\hline & Std. Deviation & 0.40 & 0.73 & 0.29 & 0.65 \\
\hline \multirow[t]{3}{*}{ Total } & Mean & -24.98 & -23.76 & -25.56 & -28.96 \\
\hline & $\mathrm{N}$ & 175 & 165 & 174 & 174 \\
\hline & Std. Deviation & 2.39 & 2.27 & 2.04 & 2.25 \\
\hline
\end{tabular}



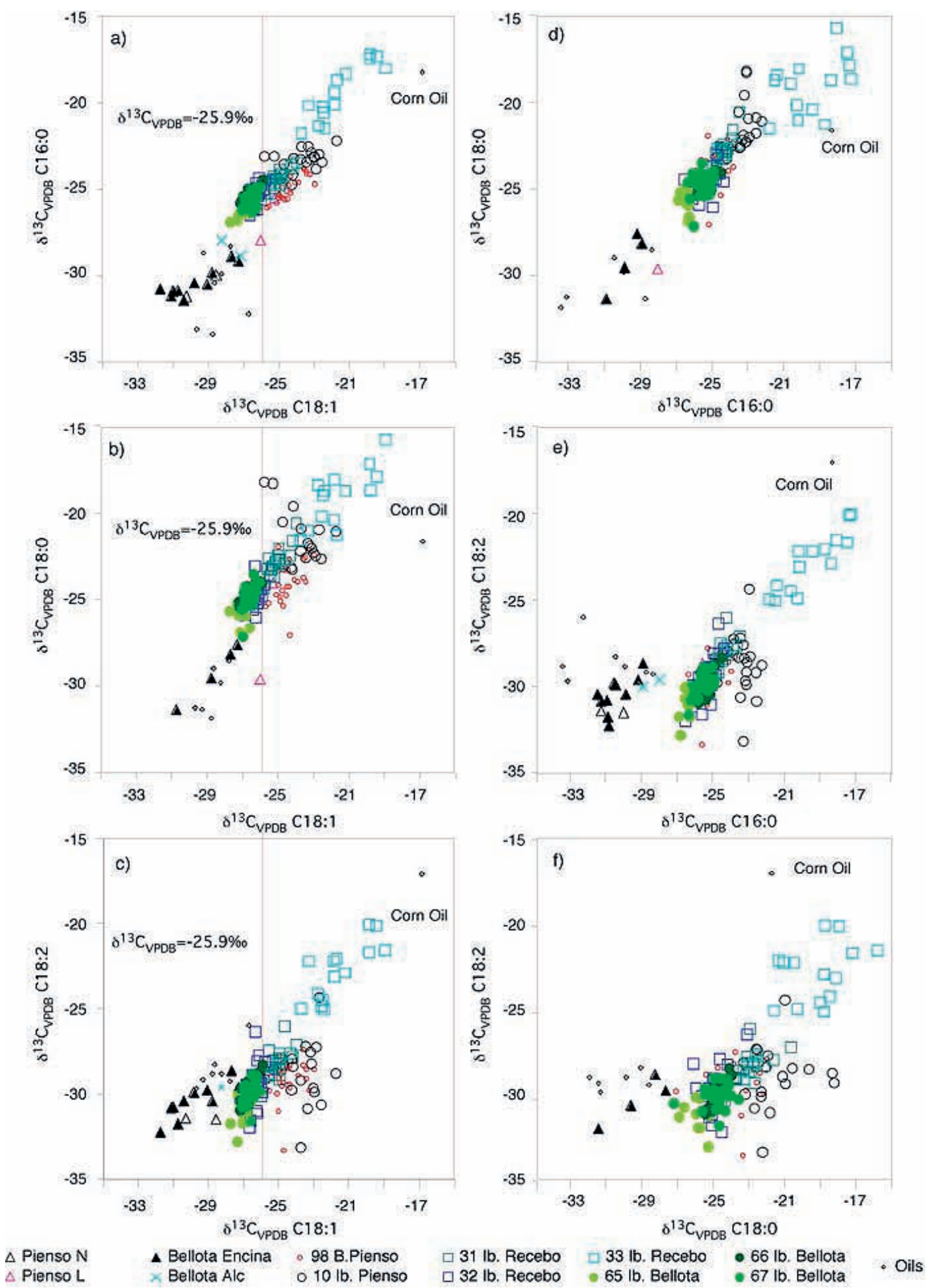

$\triangle$ Pienso L

$\begin{array}{ll}\text { Bellota Encina } & \circ 98 \text { B.Pienso } \\ \text { Bellota Alc } & \circ 10 \mathrm{lb} \text {. Pienso }\end{array}$

$\square 32 \mathrm{lb}$. Recebo

Figure 1

$\delta^{13} \mathrm{C}_{\mathrm{VPDB}}$ obtained for Palmitic (C16:0), Stearic (C18:0), Oleic (C18:1) and Linoleic (C18:2) Fatty Acids (measured as the corresponding methyl esters, and corrected for the effect of methylation), variously represented against each other. The different categories shown are described in the text, and include pork fat, acorns and feeds, together with some edible oils, analyzed for reference. Complete data set used to construct the figure available from the senior author upon request. Note that Oleic acid is a good discriminant $(a, b, c)$ : no single sample classed as Bellota has $\delta^{13} \mathrm{C}_{\mathrm{C} 18: 1}>-25.9 \%$.

used discriminator analysis to assign individual samples to the different classes, and Fig. 3 is the graphical representation of the results obtained. Function 1, which accounts for $79,4 \%$ of the variance, is mostly controlled by palmitic acid (C16:0). An additional $11,8 \%$ of the variance is explained by function 2, mostly reflecting oleic acid (C18:1). Consideration of every single batch 

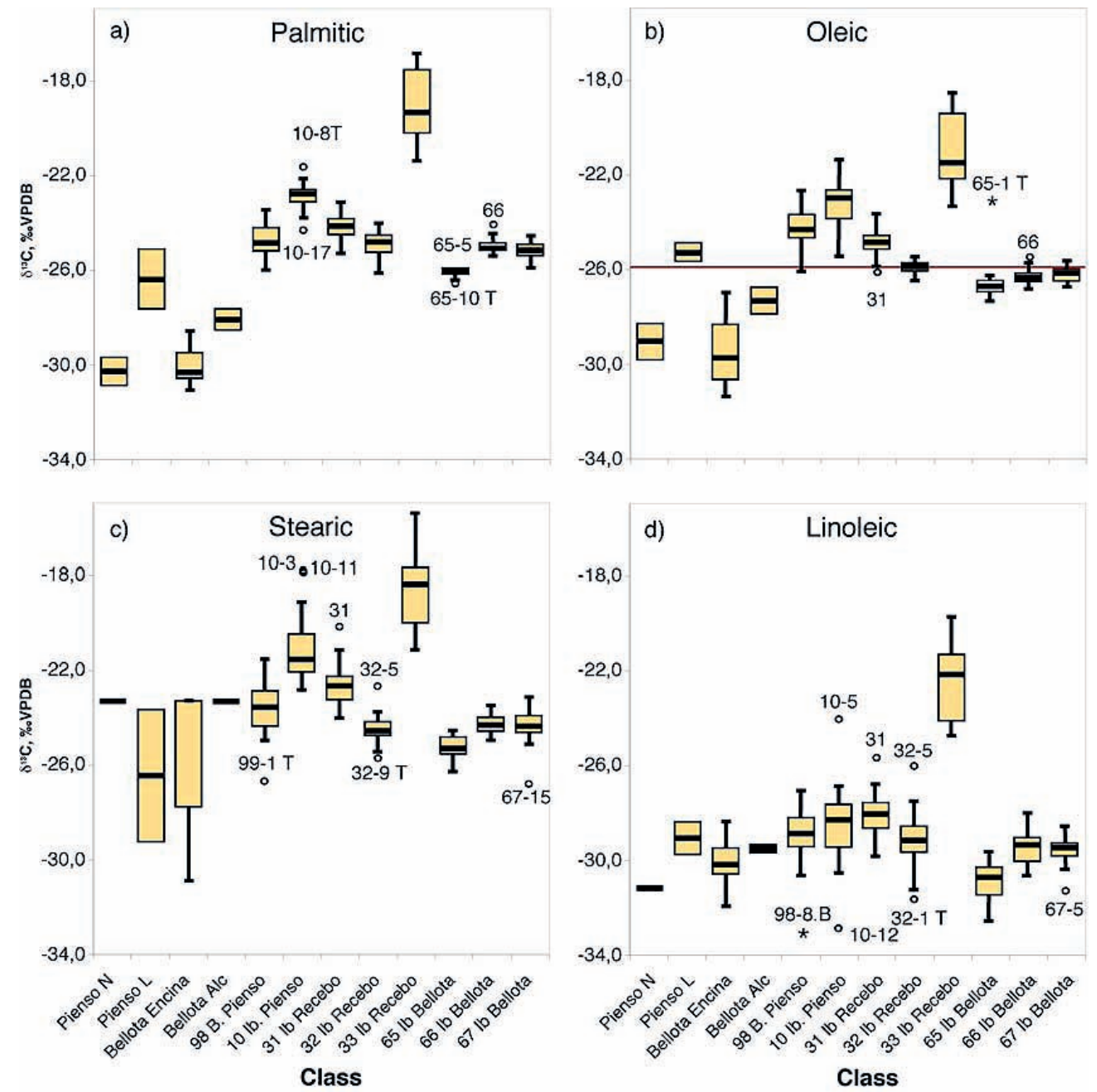

Figure 2

Mean $\delta^{13} \mathrm{C}_{\mathrm{VPDB}}$ values obtained for the fatty acids: a) Palmitic Ac. (C16:0); b) Oleic Ac. (C18:1); c) Stearic Ac. (C18:0) and d) Linoleic Ac. (C18:2), separated by class and batch. Mean $\delta^{13} \mathrm{C}_{\mathrm{C} 18: 1}$ (Oleic Acid) for acorns and acorn-fed pork are clearly lower than any other.

Table 2

ANOVA of samples considered. A significance of 0 for Snedecor's $F$ indicates that average values are indeed different for each group

\begin{tabular}{|c|c|c|c|c|c|c|}
\hline & & Sum of Squares & d.f. & Mean squares & $\mathbf{F}$ & Significance \\
\hline \multirow[t]{3}{*}{ C16:0 } & Inter-groups & 595.381 & 9 & 66.153 & 127.491 & .000 \\
\hline & Intra-groups & 79.909 & 154 & .519 & & \\
\hline & Total & 675.290 & 163 & & & \\
\hline \multirow[t]{3}{*}{ C18:0 } & Inter-groups & 662.771 & 9 & 73.641 & 63.020 & .000 \\
\hline & Intra-groups & 179.954 & 154 & 1.169 & & \\
\hline & Total & 842.725 & 163 & & & \\
\hline \multirow[t]{3}{*}{ C18:1 } & Inter-groups & 433.450 & 9 & 48.161 & 83.288 & .000 \\
\hline & Intra-groups & 89.050 & 154 & .578 & & \\
\hline & Total & 522.500 & 163 & & & \\
\hline \multirow[t]{3}{*}{ C18:2 } & Inter-groups & 624.428 & 9 & 69.381 & 49.710 & .000 \\
\hline & Intra-groups & 214.940 & 154 & 1.396 & & \\
\hline & Total & 839.368 & 163 & & & \\
\hline
\end{tabular}




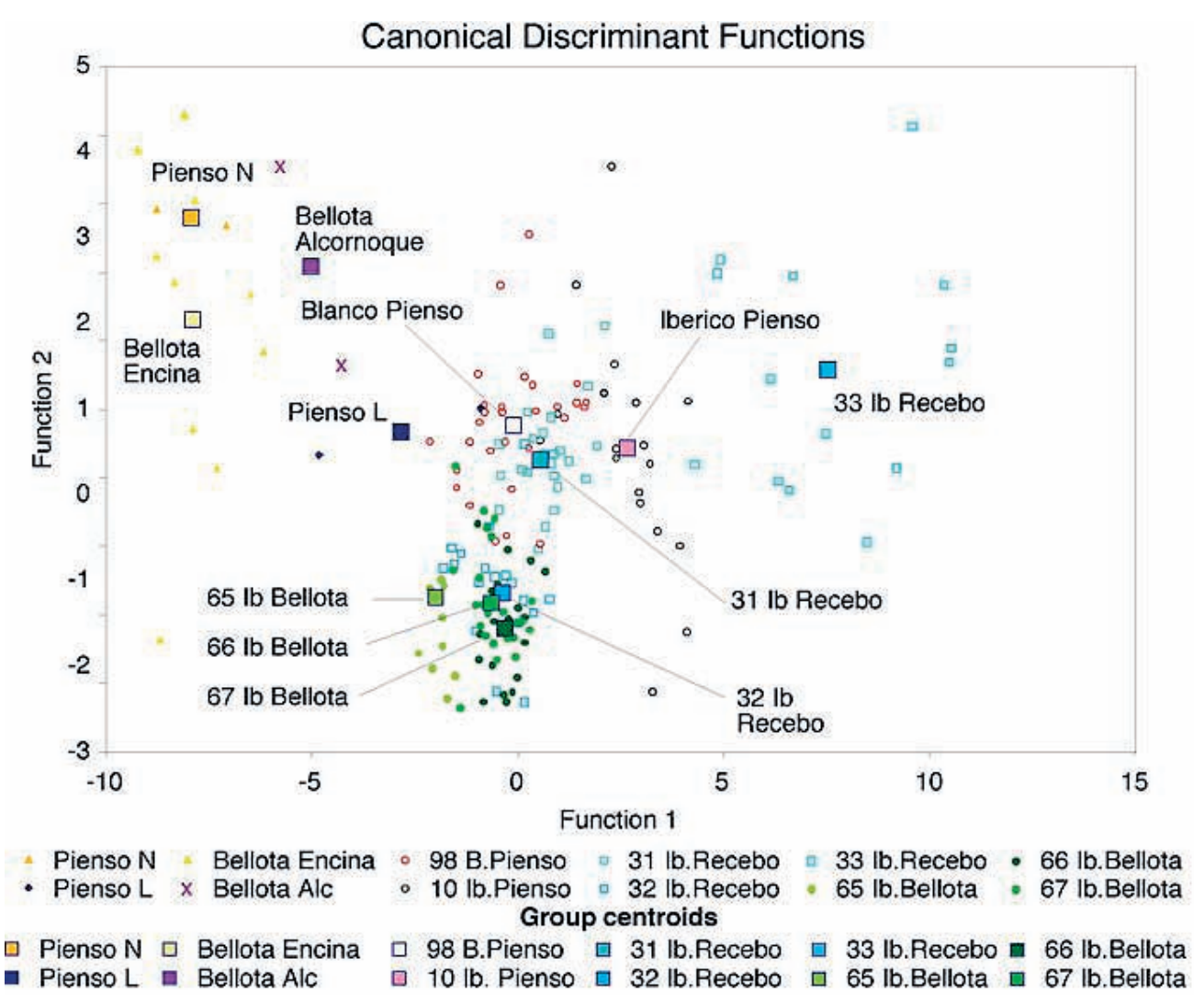

Figure 3

Plot of principal canonical components. Function 1, largely reflecting $\mathrm{C} 16: 0$, accounts for $79.4 \%$ of variance, while Function 2 , mostly controlled by $\mathrm{C} 18: 1$, represents an additional $11.8 \%$, to a cumulative total of $91.2 \%$.

as a different class results in $66.9 \%$ of the cases being correctly assigned (Table 3 ), which is good enough on its own. The situation improves, however, if the three batches a priori declared as Bellota are considered together, but not if we do the same with the three batches a priori declared as Recebo. This may result from the fact that while samples declared as Bellota are very tightly defined by legislation, and Bellota batches do approach the requirements to be classed as such, the criteria to classify a sample as Recebo are much looser (RD 144/2003; RD 1781/2004; RD 1469/2007), and allow for very different amounts of weight gain while at Montanera. Even more, the consideration of all batches declared as Recebo as a unit is clearly not justified by the data, particularly as it regards "33 lb. Recebo", which obviously was inaccurately declared to start with (Figs. 1 to 3; Tables 1 and 3).

In this context, assigning an unknown sample to one category or another can easily be done by analyzing the isotopic ratios of its FAMEs, and plotting the results in binary plots, particularly those where $\delta^{13} C_{18: 1}$ is one of the variables. Additionally, the "individual report" option of the statistical package's discriminant analysis allows for calculating the most- and next-most probable group to which a sample belongs.

\section{CONCLUSIONS AND RECOMMENDATIONS}

Several techniques that employ stable isotope analysis allow for the characterization of the pigs; their feeding regime and the pork foodstuffs derived from them. For this work we have used GC-C-IRMS analysis of FAMEs, and have found that the methyl esters of four fatty acids (palmitic, stearic, oleic and linoleic) are sufficient to discriminate among products derived from different classes of pork. The data gathered evidence strong heterogeneities among batches otherwise attributed to a common class ("Pienso", "Recebo", "Bellota"), but also within batch samples, marked differences can be shown. Such variability is not random, and hardly results from natural causes. Rather, it is highly likely that human intervention has taken a part. Inequivocal demonstration, however, requires analysis of a set of genuine samples, certified by a relevant Authority. Although not technically difficult, such "genuine" samples are currently unavailable.

We believe to have demonstrated sufficiently that the technique is sound, available, and readily applicable. The next step is therefore for the Administration (Consumer Authorities? Agriculture Administration? the Councils of the PDOs themselves?) to establish a trustworthy data base of "authentic samples", analogous, for example, to that already enforced by the European Union for the wine market (CEE Regulation No. 2676/90). 
Table 3

Classification results of canonical discriminant functions ${ }^{(a)}$ for the samples under consideration

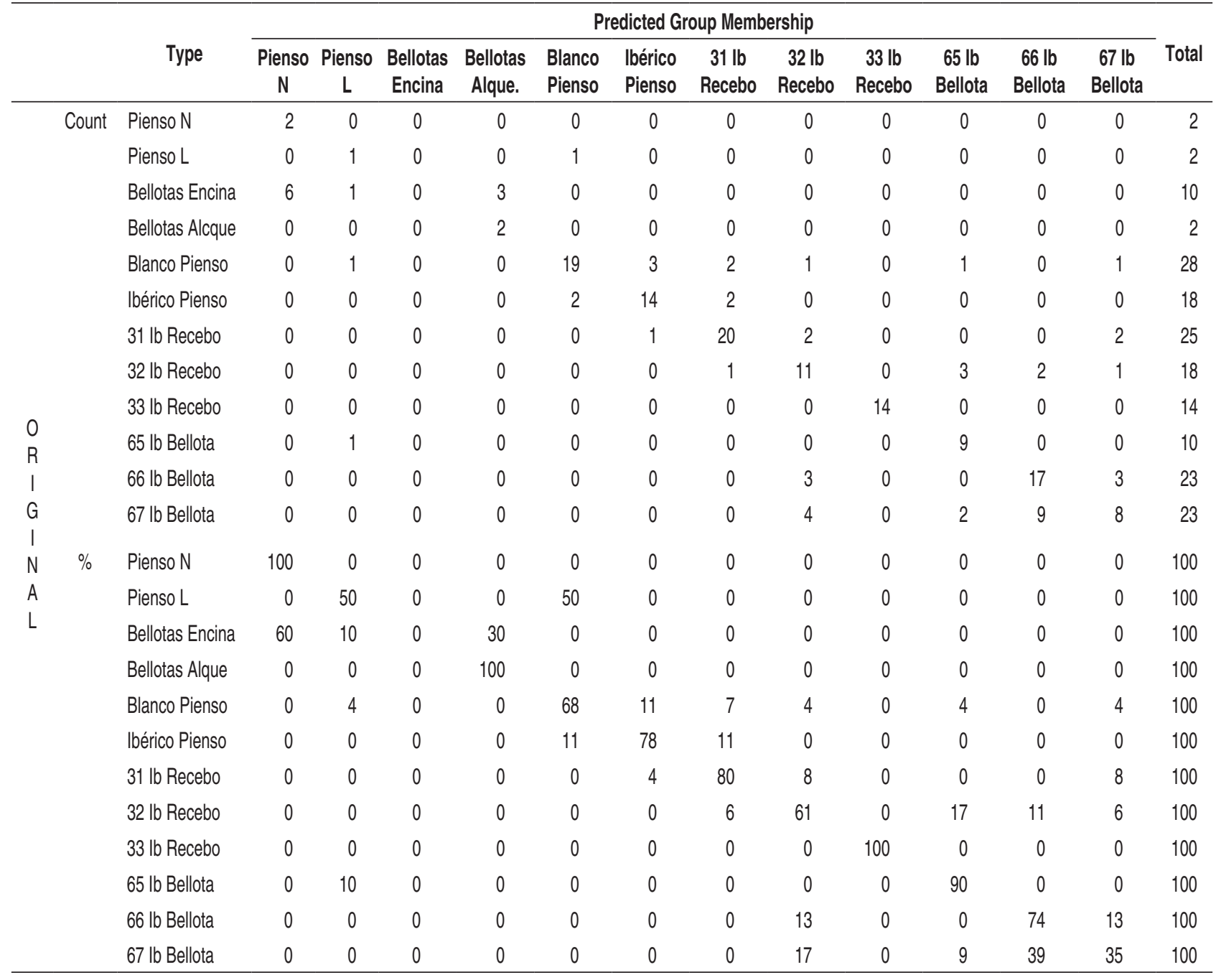

(a) $66.9 \%$ of original grouped cases correctly classified.

\section{REFERENCES}

De Pedro E, Casillas M, Miranda CM. 1996. Microwave oven application in the extraction of fat from the subcutaneous tissue of Iberian Pig ham. Meat Sci. 45, 45-51.

DeNiro MJ, Epstein S. 1978. Influence of diet on the distribution of carbon isotopes in animals. Geochim. Cosmochim. Acta 42, 495-506.

Goodman KJ, Brenna, JT. 1992. High sensitivity tracer detection using high-precision GC-C-SIRMS and highly enriched $\left[\mathrm{U}-{ }^{13} \mathrm{C}\right]$-labelled precursors. Anal. Chem. 64, 1088-1095.

González-Martín I, González-Pérez C, Hernández Méndez J, Sánchez González C. 2001. Differentiation of dietary regime of Iberian swine by means of isotopic analysis of carbon and sulphur in hepatic tissue. Meat Sci. 58, 25-30.

González-Martín I, González-Pérez C, Hernández Méndez, J, Marqués-Macias E, Sanz Poveda F. 1999. Use of isotope analysis to characterize meat from Iberian-breed swine. Meat Sci. 52, 437-441.

Meier-Augenstein W. 2002. Stable Isotopic Analysis of Fatty Acids by Gas Chromatography - Isotope Ratio Mass Spectrometry. Anal. Chim. Acta 465, 63-79.
ORDEN PRE/3844/2004, de 18 de noviembre, por la que se establecen los métodos oficiales de toma de muestras en canales de cerdos ibéricos y el método de análisis para la determinación de la composición de ácidos grasos de los lípidos totales del tejido adiposo subcutáneo de cerdos ibéricos. BOE n. 283 de 24/11/2004, pgs. 38770-38779.

REAL DECRETO 1083/2001, de 5 de octubre, por el que se aprueba la norma de calidad para el jamón ibérico, paleta ibérica y caña de lomo ibérico elaborados en España. BOE n. 247 de 15/10/2001, pgs. 3783037833.

REAL DECRETO 144/2003, de 7 de febrero, por el que se modifica el Real Decreto 1083/2001, de 5 de octubre, por el que se aprueba la norma de calidad para el jamón ibérico, paleta ibérica y caña de lomo ibérico elaborados en España. BOE n. 34 de 8/2/2003, pgs. 5156-5157.

REAL DECRETO 1469/2007, de 2 de noviembre, por el que se aprueba la norma de calidad para la carne, el jamón, la paleta y la caña de lomo ibéricos. BOE no. 264, de 3/11/2007, pgs. 45087-45104.

REAL DECRETO 1781/2004, de 30 de julio, por el que se modifica el Real Decreto 1083/2001, de 5 de octubre, por el que se aprueba la norma de calidad para el 
jamón ibérico, paleta ibérica y caña de lomo ibérico elaborados en España. BOE n. 211 de 1/9/2004, pgs. 30328-30329.

REAL DECRETO 609/1999, de 16 de abril, por el que se modifica el Real Decreto 2257/1994, de 25 de noviembre, por el que se aprueban los métodos oficiales de análisis de piensos o alimentos para animales y sus primeras materias.
REGLAMENTO (CEE) No 2676/90 DE LA COMISIÓN de 17 de septiembre de 1990 por el que se determinan los métodos de análisis comunitarios aplicables en el sector del vino.
Recibido: $16 / 10 / 12$ Aceptado: 26/1/13 